\title{
Efektivitas Kriteria Restrukturisasi Dalam Meningkatkan Kualitas Portofolio Pembiayaan
}

\author{
Oleh: \\ Hendy Herijanto \\ Restu Wulandari
}

Sekolah Tinggi Ekonomi Syariah (STES) Islamic Village Jln Raya Islamic Kelapa Dua Tangerang 15810, Indonesia

\begin{abstract}
This study aims (1) to know customer financing are consider want-not want and capable-incapable on Unit Usaha Syariah PT. Bank Tabungan Negara (2) to know the criteria of the restructuring which occur on Unit Usaha Syariah PT. Bank Tabungan Negara, and (3) to ensure that the criteria that have a positive impact on improving the financing portfolio on Unit Usaha Syariah PT. Bank Tabungan Negara. To achieve these objectives, the author uses qualitative research methodology in this is field research. Sources of data obtained directly from the study site on Unit Usaha Syariah PT. Bank Tabungan Negara from documents relating to the cases studied. In addition, the data obtained from direct interviews with Departement Head Restructuring and Recovery Collection and Workout Sharia Division dan Restructuring and Recovery Collection and Workout Officer Sharia Division. After the data were completely collected, the author analyzed the data by descriptive analysis, using the deductive analysis method, in which a specific conclusion is made from general data that have been collected. After conducting the research, it is concluded that (1) Bank in determining the customers want-not want is from the response of the customer after receiving first to third a warning letter, while in determining the customer is capable-incapable were determined by the accuracy of the promise to pay the arrears that have been agreed. (2) There are 5 (five) criteria restructuring on UUS BTN ie: hospital fees, education fees of children, fixed income but needs increase, layoffs but had returned to work, and a decrease in revenues. The whole reason is temporary, kasuistis, and the positive reasons that these criteria may be considered for approval. (3) When measured for one year from the restructuring provision, criteria of restructuring customers collectibility are still acceptable or highest Dalam Perhatian Khsusus (DPK) so that said effective.
\end{abstract} Keywords: Criteria, Restructuring, Financing Portfolio Quality 


\section{Pendahuluan}

Bank Indonesia telah menerapkan standar tingkat kesehatan bank berdasarkan lima komponen utama yaitu permodalan (Capital), kualitas aset (Asset Quality), kualitas manajemen (Management), profitabilitas (Earning), dan tingkat likuiditas (Liquidity) atau dikenal dengan CAMEL. Komponen yang mendapat bobot tertinggi menurut Bank Indonesia dalam penilaian tingkat kesehatan bank adalah kualitas aktiva produktif (Asset Quality) dengan nilai bobot sebesar 30\%. Permodalan atau rasio kecukupan modal (Capital Adequacy Ratio) dan manajemen masing-masing memiliki bobot 25\%, sedangkan unsur kemampulabaan dan likuiditas memiliki bobot $10 \%$. Persentase tersebut menunjukkan bahwa kualitas portofolio pembiayaan atau kualitas aktiva produktif mempunyai andil paling besar terhadap kesehatan bank.

Apabila persentase yang menunjukkan kualitas aktiva produktif menurun dari tahun ke tahun, maka hal itu menunjukkan bahwa portofolio pembiayaan bank tersebut mengalami tingkat masalah yang dihadapi meningkat (delinquency rate). Salah satu indikator yang menunjukkan kualitas portofolio pembiayaan perbankan adalah angka Non Performing Loan (NPL) pada perbankan konvensional atau Non Performing Financing (NPF) atau amwal mustamirah ghairuh najihah pada perbankan syariah. Kedua rasio ini di perbankan nasional masih cukup tinggi.

Otoritas Jasa Keuangan $(\mathrm{OJK})$ mencatat bahwa tingkat pembiayaan bermasalah pada bank syariah adalah sebesar 4,8\% secara nasional, bahkan lebih tinggi dari angka kredit macet bank konvensional 2,7\% (Solo Pos, 11/12/2015).

Upaya menekan NPF dilakukan baik secara preventif maupun kuratif. Contoh cara preventif adalah dengan meningkatkan kemampuan sumber daya manusia dan edukasi proses pemberian pembiayaan dengan prinsip kehati-hatian (Prudential). Agustianto Mingka mengatakan, bahwa bank syariah dalam hal penyaluran pembiayaan harus dilakukan berdasarkan prinsip kehati-hatian (ihtiyath, prudential), yang tidak hanya mengejar target semata atau dipengaruhi oleh faktor-faktor tertentu lainnya, misalnya pengaruh politik dan KKN. Salah satu cara untuk menerapkan prinsip ini adalah memilih usaha yang telah stabil dan prospektif, serta menetapkan limit dari setiap pembiayaan yang diberikan. Secara kuratif, bank syariah dapat melakukan restrukturisasi pembiayaan yang bermasalah, atau melakukan upaya hukum untuk menyelamatkan pembiayaan.

Terdapat beberapa golongan nasabah penyumbang NPF, dan tulisan ini membatasi diri hanya pada nasabah individu atau perorangan. Pertama, golongan nasabah yang tidak mau pembiayaan dan sudah tidak mampu secara financial. Kedua, golongan nasabah yang masih mau melanjutkan 
pembiayaan, tetapi sudah tidak mampu mengangsur kewajiban kepada bank. Ketiga, nasabah golongan mampu melanjutkan pembiayaan, tetapi tidak mau membayar angsuran pembiayaan. Keempat, golongan nasabah yang masih mau membayar kewajiban dan masih mampu. Upaya yang dapat ditempuh untuk penyelamatan pembiayaan bermasalah tiap golongan berbeda.

Untuk nasabah golongan mau-tidak mampu dapat dilakukan restrukturisasi pembiayaan, sehingga nasabah dapat melanjutkan mengangsur kewajiban kepada bank syariah. Umumnya, nasabah pembiayaan mengalami masalah dalam mengangsur jika pendapatannya mengalami penurunan, dan sebagai akibatnya tidak dapat membayar seperti yang diperjanjikan. Keadaan ini diperparah, jika nasabah tidak segera berkonsultasi dengan pihak bank karena keterbatasan pengetahuan, sehingga tunggakan pembayaran kewajiban berakumulasi. Akumulasi tunggakan ini dapat diatasi dengan cara merestrukturisasi kewajiban pembayaran. Restrukturisasi dilakukan dengan menetapkan angka yang lebih rendah dan waktu yang lebih panjang, yang disesuaikan dengan keadaan kemampuan yang ada. Dengan demikian, nasabah yang kewajibannya telah direstrukturisasi dapat memenuhi kewajibannya dengan lebih lancar.

A Wangsawidjaja (2012:448) berpendapat bahwa restrukturisasi adalah upaya bank untuk membantu nasabah yang masih prospektif tetap dapat menjalankan usahanya, dan dapat menyelesaikan kewajibannya kepada bank. Ini sejalan dengan pasal 5 ayat 1 Peraturan Bank Indonesia 10/18/PBI/2008 bahwa: "Restrukturisasi pembiayaan hanya dapat dilakukan untuk nasabah yang memenuhi kriteria sebagai berikut: a. nasabah memiliki penurunan kemampuan pembayaran ; dan b. nasabah memiliki prospek usaha yang baik dan mampu memenuhi kewajiban setelah restrukturisasi."

Penyebab nasabah mengajukan restrukturisasi pada Unit Usaha Syariah PT. Bank Tabungan Negara, umumnya karena PHK, mengundurkan diri dari pekerjaan atau resign dan kebutuhan mendesak. Nasabah yang mengalami PHK atau resign tidak lagi memiliki pendapatan tetap, sehingga tidak dapat membayar kewajiban angsuran kepada bank. Hal tersebut terjadi untuk jangka waktu yang tidak dapat ditentukan, sejauh nasabah belum mendapat pekerjaan baru atau mendapatkan sumber penghasilan lain, sehingga terjadi tunggakan berakumulasi dan menjadi penyumbang NPF bagi bank.

Berdasarkan uraian di atas, permasalahan yang akan diteliti adalah apakah penyebab nasabah tidak melakukan pembayaran angsuran karena mengalami PHK atau resign dan kebutuhan mendesak itu akan patuh dan mampu membayar kewajiban angsuran setelah 
direstrukturisasi. Restrukturisasi yang dilakukan harus mengacu kepada Peraturan Bank Indonesia nomor: 10/18/PBI/2008 pasal 5 ayat 1 butir b yang telah disebutkan sebelumnya.

\section{Pengertian Efektivitas}

Kata efektif berasal dari bahasa inggris yaitu effective yang berarti berhasil atau sesuatu yang dilakukan berhasil dengan baik. Kamus ilmiah populer mendefinisikan efektivitas sebagai ketepatan penggunaan, hasil guna atau menunjang tujuan. Suatu bank dikatakan efektif apabila dapat menunjang pertumbuhan ekonomi, dan akhirnya menciptakan kesejahteraan masyarakat secara lebih luas (Herijanto, 2013:106). Tujuan perbankan syariah sesuai pasal 3 Undang-Undang Republik Indonesia Nomor 21 Tahun 2008 tentang perbankan syariah yaitu:“Perbankan syariah bertujuan menunjang pelaksanaan pembangunan nasional dalam rangka meningkatkan keadilan, kebersamaan, dan pemerataan kesejahteraan rakyat." Apabila tercapainya tujuan dimaksud bank dapat dikatakan efektif.

\section{Kesehatan Bank}

Menurut Pasal 51 Ayat 1 Undang-Undang Nomor 21 Tahun 2008 Tentang Perbankan Syariah bahwa Bank syariah dan UUS wajib memelihara tingkat kesehatan yang meliputi sekurang-kurangnya mengenai kecukupan modal, kualitas aset, likuiditas, rentabilitas, solvabilitas, kualitas manajemen yang menggambarkan kapabilitas dalam aspek keuangan, kepatuhan terhadap prinsip syariah dan prinsip manajemen Islami, serta aspek lainnya yang berhubungan dengan usaha Bank syariah dan UUS.

Salah satu ciri bank dalam katagori sehat adalah bank yang memiliki Non NPF yang relatif rendah dalam portofolio pembiayaan yang diberikannya. NPF yang rendah akan mengurangi tingkat risiko yang dihadapi sekaligus meningkatkan tingkat solvabilitas bank (Herijanto, 2013:108).

\section{Metode CAMEL}

Analisa rasio CAMEL dalam menilai kinerja keuangan bank berdasarkan Surat Edaran Bank Indonesia No. 9/24/DPbS tanggal 30 Oktober 2007 meliputi:

\section{Permodalan (Capital)}

Menurut Pasal 2 PBI No. 7/13/PBI/2005 Tentang Kewajiban Penyediaan Modal Minimum Bank Umum Berdasarkan Prinsip Syariah bahwa: "Bank wajib menyediakan modal minimum sebesar 8\% (delapan 
perseratus) dari aktiva tertimbang menurut risiko." Terkait dengan NPF terhadap Permodalan (Capital), peningkatan jumlah NPF akan meningkatkan jumlah PPAP yang perlu dibentuk oleh pihak bank. Jika hal ini berlangsung secara terus menerus maka akan mengurangi modal bank (Zaenuri, 2014:121).

\section{Kualitas Aset (Asset Quality)}

Kualitas Aktiva Produktif (KAP) berpengaruh pada tingkat profitabilitas karena penanaman dana yang dilakukan oleh bank adalah pada aktiva produktif, sehingga KAP harus dipertahankan dalam keadaan lancar. Semakin baik kualitas aktiva produktif suatu bank maka semakin kecil pembiayaan bermasalah pada bank tersebut, dan kecilnya pembiayaan bermasalah pada suatu bank maka tingkat profitabilitasnya semakin baik (Dimaelita, 2007 dalam Ika, 2008:5). Salah satu contoh dampak buruk dari NPF adalah kejadian pada Bank Islam Malaysia (BIM) Berhad pada tahun 2005 yang mengalami kerugian RM 456 juta karena NPF senilai RM 2,2 miliar (Herijanto, 2013:275).

\section{Manajemen (Management)}

Penilaian manajemen dimaksudkan untuk menilai kemampuan manajerial pengurus bank dalam menjalankan usaha sesuai dengan prinsip manajemen umum, kecukupan manajemen risiko dan kepatuhan bank terhadap ketentuan baik yang terkait dengan prinsip kehati-hatian maupun kepatuhan terhadap prinsip syariah dan komitmen kepada Bank Indonesia.

Herijanto (2013:108) menjelaskan bahwa salah satu prinsip pemberian pembiayaan yang sehat adalah yang dapat menunjang pengembangan usaha calon nasabah. Pembayaran yang lebih pasti kepada bank akan mengurangi tingkat risiko yang harus dihadapi, sekaligus meningkatkan tingkat solvabilitas bank. Diabaikannya prinsip pemberian pembiayaan yang sehat dapat menimbulkan NPF yang besar. Kualitas portofolio yang rendah atau rasio NPF yang tinggi di antaranya karena pengambilan risiko pembiayaan yang berlebihan.

Contoh dampak buruk dari adverse selection dalam manajemen adalah Bank Islam di Sudan, NPF yang terjadi disebabkan karena penilaian pemberian pembiayaan yang lemah, dan tidak menerapkan tugas diverkasi risiko yang layaknya dilakukan oleh bank (Herijanto, 2013:276).

\section{Rentabilitas (Earnings)}

Penilaian rentabilitas dimaksudkan untuk menilai kemampuan bank dalam menghasilkan laba. Non Performing Financing (NPF) ikut mempengaruhi pencapaian laba bank, menurut Suhada (2009) sebagaimana yang dikutip Lukito Pamungkas, (2014:10). Selain itu tingginya rasio NPF juga mengakibatkan tingginya Penyisihan Penyusutan Aktiva Produktif (PPAP) bank. Dengan tingginya PPAP ini maka bank 
kehilangan kesempatannya untuk memperoleh pendapatan dari penyaluran pembiayaannya karena dana yang dimiliki dialokasikan untuk PPAP yang pada akhirnya mengurangi laba (Purwanto, 2011:43).

\section{Likuiditas (Liquidity)}

Likuiditas yang tersedia pada bank harus cukup, tidak boleh terlalu kecil sehingga mengganggu kebutuhan operasional sehari-hari, namun juga tidak boleh terlalu besar karena akan menurunkan efisiensi dan berdampak pada rendahnya tingkat profitabilitas (Latvia, 2013:47). Likuiditas menurut Kasmir (2002:286) merupakan kemampuan bank dalam memenuhi kewajiban jangka pendeknya pada saat ditagih. Dengan kata lain, bank dapat membayar kembali ketika nasabah mencairkan depositnya dan dapat memenuhi pembiayaan yang diajukan. Apabila tingkat gagal bayar nasabah pembiayaan untuk memenuhi kewajibannya membesar yang membuat NPF meninggi, maka kedua hal ini berpengaruh terhadap likuiditas bank seperti hasil penelitian yang dilakukan Hidayati (2014:105) dan Mustafidan (2013:78).

\section{Kualitas Pembiayaan}

\section{Pembiayaan bermasalah atau Non Performing Financing (NPF)}

Herijanto (2013:122) mengatakan bahwa NPF akan tercipta, jika nasabahnya tidak melakukan pembayaran angsuran terhadap harga dari satuan pembelian yang telah disepakati, atau tidak berhasil menciptakan keuntungan seperti yang direncanakan dalam kurun waktu yang berjalan. Ini lebih lanjut berarti bank tidak lagi dapat mengakui, dan mencatat adanya perolehan bagian keuntungan tersebut.

Wangsawidjaja (2012:90) mengatakan bahwa pembiayaan bermasalah, dari segi produktivitasnya (performance-nya), yaitu dalam kaitannya dengan kemampuannya menghasilkan pendapatan bagi bank, sudah berkurang / menurun dan bahkan mungkin sudah tidak ada lagi. Bahkan dari sisi Bank, sudah tentu mengurangi pendapatan dan memperbesar biaya pencadangan, yaitu Penyisihan Penghapusan Aktiva (PPA), sedangkan dari sisi nasional, mengurangi kontribusinya terhadap pembangunan dan pertumbuhan ekonomi.

\section{Faktor-Faktor Penyebab Pembiayaan Bermasalah}

Kasmir (2004:128) dalam Meilasari (2014:17), dalam praktiknya suatu pembiayaan macet karena 2 unsur sebagai berikut:

a. Dari pihak Perbankan. Artinya dalam melakukan analisisnya, pihak analis kurang teliti sehingga apa yang seharusnya terjadi tidak diprediksi sebelumnya, atau mungkin salah melakukan perhitungan. Dapat pula terjadi akibat kolusi dari pihak analis dengan pihak Nasabah sehingga dalam analisisnya dilakukan secara subyektif dan akal- akalan. 
b. Dari pihak nasabah. Dari pihak nasabah kemacetan pembiayaan dapat dilakukan akibat 2 hal yaitu:

1) Adanya unsur kesengajaan. Dalam hal ini nasabah sengaja untuk tidak bermaksud membayar kewajibannya kepada bank sehingga pembiayaan yang diberikan macet. Dapat dikatakan tidak adanya unsur kemauan untuk membayar, walaupun sebenarnya nasabah mampu.

2) Adanya unsur ketidaksengajaan. Artinya nasabah mau membayar akan tetapi tidak mampu. Sebagai contoh pembiayaan yang dibiayai mengalami musibah seperti kebakaran, hama, kebanjiran dan sebagainya sehingga kemampuan membayar tidak ada.

\section{Penyelamatan Pembiayaan Bermasalah}

Penyelamatan pembiayaan bermasalah adalah upaya penaggulangan yang bersifat kuratif/represif untuk menekan laju NPF atau pembiayaan bermasalah.

\section{Definisi Restrukturisasi}

Definisi Restrukturisasi menurut Peraturan Bank Indonesia No. 10/18/PBI/2008 tanggal 25 September 2008 tentang Restrukturisasi Pembiayaan bagi Bank Umum Syariah dan Unit Usaha Syariah, sebagaimana telah diubah dengan PBI No. 13/9/PBI/2011 tanggal 8 Februari 2011, adalah sebagai berikut: "Restrukturisasi Pembiayaan adalah upaya yang dilakukan oleh Bank dalam rangka membantu nasabah agar dapat menyelesaikan kewajibannya, antara lain melalui:

i. Penjadwalan kembali (rescheduling), yaitu perubahan jadwal pembayaran kewajiban nasabah atau jangka waktunya;

ii. Persyaratan kembali (reconditioning), yaitu perubahan sebagian atau seluruh persyaratan pembiayaan, antara lain perubahan jadwal pembayaran, jumlah angsuran, jangka waktu dan/atau pemberian potongan sepanjang tidak menambah sisa kewajiban nasabah yang harus dibayarkan kepada Bank;

iii. Penataan kembali (restructuring), yaitu perubahan persyaratan pembiayaan tidak terbatas pada rescheduling atau reconditioning, antara lain meliputi:

1. penambahan dana fasilitas pembiayaan Bank;

2. koversi akad pembiayaan;

3. konversi akad pembiayaan menjadi surat berharga syariah berjangka waktu menengah;

4. konversi pembiayaan menjadi penyertaan modal sementara pada perusahaan nasabah." 


\section{Analisis Terhadap Pembiayaan Restrukturisasi}

Wangsawidjaja (2012:451) menyebutkan mengenai keharusan analisis pembiayaan yang akan dilakukan resturkturisasi sesuai dengan angka III Surat Edaran Bank Indonesia Nomor 10/34/DPbS tanggal 22 Oktober 2008.

\section{Metode Penelitian}

Penelitian ini bersifat penelitian lapangan (field research) yaitu penelitian yang dilakukan dalam kehidupan atau penelitian yang objek sebenarnya berupa fakta empiris dengan menggunakan data konkrit. Teknik pengambilan data penelitian ini menggunakan sampel dari jumlah populasi nasabah yang melakukan restrukturisasi pembiayaan yang ada pada Unit Usaha Syariah PT. Bank Tabungan Negara dengan melihat laporan restrukturisasi pembiayaan.

\section{Jenis Data}

Data yang digunakan adalah nasabah-nasabah yang ada di bank syariah dan dilakukan restrukturisasi oleh bank tersebut. Jadi, data tersebut bersifat sekunder. Dari data yang diperoleh itu diteliti apakah nasabah tersebut berada pada tingkat kesehatan yang masih diterima pada akhir periode penelitian.

\section{Populasi dan Sampel}

Populasi penelitian ini adalah seluruh nasabah restrukturisasi perorangan pada bulan Januari 2015, Maret 2015, dan Juni 2015. Metode pengambilan sampel yang digunakan adalah purposive sampling atau pengambilan sampel berdasarkan tujuan tertentu. Purposive sampling adalah suatu teknik pengambilan sampel dengan unit-unit analisis (satuansatuan sampel) yang diambil dan ditentukan oleh peneliti, berdasarkan tujuan-tujuan yang sesuai dengan maksud dan tujuan penelitian (Syah, 2010:150).

\section{Metode Pengumpulan Data}

Untuk mendapat data yang lebih valid dan akurat, penulis menggunakan metode berikut:

1. Dokumentasi, yaitu mengambil dari dokumen-dokumen yang berkaitan dengan permasalahan yang diteliti, data pembiayaan yang bermasalah, data restrukturisasi pembiayaan bermasalah dan profil bank.

2. Wawancara untuk memperoleh keterangan mengenai alasan-alasan nasabah yang direstrukturisasi menjadi lancar atau kembali bermasalah. 


\section{Kebijakan Restrukturisasi}

1. Peraturan Direksi dan Surat Edaran Direksi Perihal Restrukturisasi. Menurut Pasal 10 Ayat 1 Peraturan Bank Indonesia Nomor: 10/18/PBI/2008 25 September 2008 Tentang Restrukturisasi Pembiayaan Bagi Bank Syariah dan Unit Usaha Syariah sebagaimana telah diubah dengan PBI No. 13/9/PBI/2011 tanggal 8 Februari 2011 dijelaskan bahwa Bank wajib memiliki kebijakan dan Standard Operating Procedure tertulis mengenai Restrukturisasi Pembiayaan. Kebijakan restrukturisasi pembiayaan pada Unit Usaha Syariah PT. Bank Tabungan Negara telah diatur dalam Peraturan Direksi dan pada Surat Edaran Direksi. Pejabat bank pemutus restrukturisasi tidak boleh pejabat pemutus pembiayaan terkait. Selanjutnya, di dalam Surat Edaran Direksi juga memuat limit memutus berdasarkan ketentuan plafond pembiayaan dan nominal keringanan yang diberikan.

2. Penentuan Nasabah Mau-Tidak Mau dan Mampu-Tidak Mampu Secara Financial

\section{a. Nasabah Mau-Tidak Mau}

Pembinaan proaktif yang dilakukan oleh bank dalam menurunkan NPF dengan cara menghubungi lewat telpon, sms dan kunjungan ke alamat agunan, alamat instansi atau alamat lain nasabah dapat memberikan informasi tentang kemauan nasabah dalam hal melanjutkan pembiayaan. Pegawai bank dapat mengetahui hal tersebut langsung dari pernyataan nasabah itu sendiri, ataupun dari respon nasabah setelah diberikan surat peringatan pertama sampai ketiga. Nasabah yang masih mau melanjutkan pembiayaan biasanya mempunyai itikad baik untuk membicarakan bagaimana mereka dapat menyelesaikan pembayaran tunggakan kepada bank.

Nasabah yang secara langsung menyatakan sudah tidak mau melanjutkan pembiayaan biasanya tidak mempunyai itikad baik untuk menyelesaikan tunggakan. Dari keadaan ini dapat disimpulkan bahwa statusnya sudah tidak mau. Golongan nasabah yang masih mau melanjutkan pembiayaan adalah nasabah yang mau menyelesaikan tunggakan sekaligus maupun bersedia membicarakan kepada bank.

\section{b. Nasabah Mampu-Tidak Mampu}

Pegawai bank dapat mengetahui informasi tentang kemampuan financial nasabah setelah melakukan pembinaan proaktif dalam menurunkan NPF dengan cara menghubungi lewat telpon, sms dan kunjungan ke alamat agunan, alamat instansi atau alamat lain untuk mengingatkan tunggakan angsuran pembiayaan nasabah.

Nasabah biasanya akan menjelaskan alasan terjadinya tunggakan angsuran pembiayaan kepada pegawai bank pada saat 
dihubungi, dan memberikan tanggal janji pembayaran pertama atas tunggakan dimaksud. Nasabah yang mampu biasanya akan menepati tanggal janji pembayaran pertama. Namun, terdapat juga nasabah yang tidak melakukan pembayaran pertamanya pada tanggal yang disepakati.

Terdapat dua kemungkinan bagi nasabah yang tidak melakukan pembayaran pertamanya pada tanggal yang telah disepakati: Pertama, yaitu nasabah menjanjikan pembayaran pada tanggal lain. Kedua, nasabah tersebut datang ke bank untuk membicarakan alternatif lain dalam rangka mempermudah pelaksanaannya. Dari uraian tersebut di atas, dapat ditarik kesimpulan bahwa nasabah yang membayar pada tanggal janji bayar pertama dan meleset pada janji bayar pertama namun membayar di tanggal lain masih digolongkan nasabah mampu. Disamping itu nasabah yang datang ke bank untuk membicarakan alternatif pembayaran lain adalah nasabah yang masih mau menyelesaikan kewajibannya, tetapi kemampuan keuangannya berkurang.

\section{Penetapan Kualitas Pembiayaan Setelah Restrukturisasi}

Menurut Pasal 11 Ayat 1 Peraturan Bank Indonesia Nomor: 10/18/PBI/2008 Tanggal 25 September 2008 Tentang Restrukturisasi Pembiayaan Bagi Bank Syariah dan Unit Usaha Syariah sebagaimana telah diubah dengan PBI No. 13/9/PBI/2011 tanggal 8 Februari 2011 bahwa kualitas pembiayaan setelah dilakukan restrukturisasi ditetapkan sebagai berikut:

a. Paling tinggi Kurang Lancar untuk pembiayaan yang sebelum dilakukan restrukturisasi tergolong Diragukan atau Macet;

b. Tidak berubah untuk pembiayaan yang sebelum dilakukan restrukturisasi tergolong Lancar, Dalam Perhatian Khusus, atau Kurang Lancar.

Selanjutnya pada Ayat 2 disebutkan mengenai kualitas pembiayaan setelah ketetapan pada Ayat 1 di atas. Kualitas Pembiayaan sebagaimana dimaksud pada ayat (1) dapat:

a. $\quad$ Menjadi Lancar, apabila tidak terdapat tunggakan selama 3 (tiga) kali periode pembayaran angsuran pokok dan/atau margin/bagi hasil/fee/ujrah secara berturut-turut sesuai dengan perjanjian Restrukturisasi Pembiayaan; atau

b. Menjadi sama dengan kualitas Pembiayaan sebelum dilakukan Restrukturisasi Pembiayaan atau menjadi lebih buruk, jika nasabah tidak memenuhi kriteria dan/atau syarat-syarat dalam perjanjian Restrukturisasi Pembiayaan dan/atau pelaksanaan Restrukturisasi 
Pembiayaan tidak didukung dengan analisis dan dokumentasi yang memadai;

c. Dalam hal periode pembayaran angsuran pokok dan/atau margin/bagi hasil/fee/ujrah kurang dari 1 (satu) bulan, peningkatan kualitas menjadi Lancar sebagaimana dimaksud pada ayat (2) huruf a dapat dilakukan paling cepat dalam waktu 3 (tiga) bulan sejak dilakukan Restrukturisasi Pembiayaan;

Mengacu pada Peraturan Bank Indonesia tersebut di atas, Unit Usaha Syariah PT. Bank Tabungan Negara menjelaskan mengenai penetapan tersebut adalah sebagai berikut:

a. Paling tinggi sama dengan kualitas pembiayaan sebelum dilakukan Restrukturisasi, sepanjang nasabah belum memenuhi kewajiban pembayaran angsuran pokok dan/atau margin secara berturut-turut selama 3 (tiga) kali periode sesuai waktu yang diperjanjikan;

b. Dapat meningkat paling tinggi 1 (satu) tingkat dari kualitas pembiayaan sebelum dilakukan Restrukturisasi, setelah nasabah memenuhi kewajiban pembayaran angsuran pokok dan/atau margin secara berturut-turut selama 3 (tiga) kali periode sebagaimana dimaksud huruf a; dan

c. Berdasarkan faktor penilaian prospek usaha, kinerja (performance) Debitur dan kemampuan membayar, yaitu:

1) Setelah penetapan kualitas pembiayaan sebagaimana dimaksud huruf b;

2) Dalam hal nasabah tidak memenuhi syarat-syarat dan/atau kewajiban pembayaran dalam perjanjian Restrukturisasi, baik selama maupun setelah 3 (tiga) kali periode kewajiban pembayaran sesuai dengan yang diperjanjikan.

\section{Pelaksanaan Restrukturisasi}

Pembiayaan bermasalah dilatar belakangi oleh banyak hal yang berkaitan dengan nasabah. Menurut Amsal Yusuph, alasan nasabah bermasalah terbagi menjadi 2 kategori. Pertama, karena karakter yang tidak baik. Nasabah dengan sadar tidak membayar kewajiban angsuran padahal secara financial masih tergolong mampu. Kedua, karena ketidakmampuan financial. Contoh alasan yang terjadi umumnya karena PHK, pindah kerja, biaya rumah sakit ketika ada anggota keluarga yang sakit, perceraian yang mengakibatkan sumber pendapatan menjadi single income yang sebelumnya joint income. (dalam wawancara bersama Departement Head Restructuring and Recovery Collection and Workout Sharia Division pada 15/09/2016).

Terdapat empat golongan nasabah pada Gambar 4.1 di atas. Pada kuadran I, bagi nasabah Mau-Mampu: perlakuan bank adalah melakukan 
penagihan secara intensif kepada nasabah dengan cara melakukan pembinaan proaktif dalam menurunkan NPF dan menghubungi lewat telpon, sms serta kunjungan ke alamat agunan, alamat instansi atau alamat lain untuk mengingatkan adanya tunggakan angsuran pembiayaan nasabah.

Selanjutnya, golongan nasabah pada kuadran II dan III, yaitu Tidak Mau-Mampu dan Tidak Mau-Tidak Mampu: perlakuan bank adalah melakukan litigasi atas agunan nasabah dalam rangka penyelamatan pembiayaan. Hal tersebut dilakukan untuk menurunkan angka NPF.

Golongan pada kuadran IV adalah nasabah Mau-Tidak Mampu: perlakuan bank terhadap nasabah ini adalah menggunakan cara restrukturisasi. Nasabah yang mengalami permasalahan keuangan temporer ini biasanya disebabkan karena harus membayar biaya anak sekolah, biaya rumah sakit apabila ada keluarganya sakit dan mengalami PHK tetapi baru memperoleh pekerjaan. Alasan-alasan ini menunjukan bahwa keadaan yang dihadapi hanya sementara dan setelah itu nasabah yang terkait memulai angsuran kembali setelah diberikan restrukturisasi.

Kondisi keuangan menurun juga merupakan masalah yang dihadapi nasabah golongan ini. Contoh yang terjadi adalah nasabah mengalami perceraian. Sebelumnya pendapatan keluarga bersifat joint income. Karena perceraian pendapatan tersebut berubah menjadi single income. Bagi salah satu pasangan yang berpenghasilan lebih kecil, maka yang bersangkutan mengalami kesulitan membayar angsuran. Sebagai contoh, apabila pasangan suami dan istri mengalami perceraian, di mana nasabah merupakan istri yang berpenghasilan lebih kecil dibanding suami, maka walaupun sudah bercerai suami wajib membantu pembayaran angsuran ke bank. Contoh lain karena pernah PHK dan setelah mendapat pekerjaan baru, salary yang didapat lebih kecil dari perusahaan sebelumnya. Pendapatan yang tetap dari tahun ke tahun dengan kebutuhan meningkat secara terus menerus juga menyebabkan kondisi keuangan menurun.

Nasabah golongan ini cenderung membicarakan bagaimana mereka dapat menyelesaikan pembayaran tunggakan kepada bank dengan alternatif lain. Dalam menghadapi nasabah seperti ini, bank melakukan restrukturisasi pembiayaan dengan menyesuaikan kondisi jumlah angsuran dengan keuangan nasabah.

\section{Kesimpulan}

Berdasarkan uraian pada Bagian IV yang telah dijelaskan sebelumnya, penulis dapat menarik kesimpulan sebagai berikut:

a. UUS BTN menentukan kriteria nasabah Mau-Tidak mau adalah dari respon nasabah setelah diberikan surat peringatan pertama sampai surat peringatan ketiga. Sedangkan, untuk menentukan nasabah 
Mampu-Tidak mampu dapat ditentukan dengan ketepatan janji bayar tunggakan yang telah disepakati bersama. Selanjutnya, kebijakan dan ketentuan mengenai restrukturisasi pembiayaan yang dimiliki oleh UUS BTN sudah sesuai dengan Peraturan Bank Indonesia serta implementasi kepatuhan pelaksanaan pemberian restrukturisasi terhadap peraturan tersebut dapat dilihat dari ketatnya analisa kantor cabang dan kantor pusat dalam menentukan Re-Payment Capacity (RPC) nasabah.

b. Terdapat 5 (Lima) kriteria nasabah yang dilakukan restrukturisasi oleh UUS BTN yaitu: Biaya rumah sakit, Biaya pendidikan anak, Kebutuhan meningkat pendapatan tetap, Pernah PHK namun sudah bekerja kembali, Penurunan Pendapatan. Seluruh kriteria tersebut bersifat temporer, kasuistis, dan merupakan alasan positif sehingga dapat dipertimbangkan untuk disetujui. Masalah yang dihadapi nasabah bersifat sementara dan tidak berulang, kesimpulan tersebut ditarik dengan melihat bahwa setelah satu tahun semenjak restrukturisasi nasabah masih dalam kolektibilitas yang masih dapat diterima (perform) atau paling tinggi Dalam Perhatian Khusus (DPK).

c. Pada pelaksanaannya, seluruh kriteria yang dilakukan restrukturisasi yang sebelumnya tidak perform atau NPF memberikan efektivitas dalam meningkatkan kualitas portofolio pembiayaan karena setelah diukur selama 1 (satu) tahun, seluruh kolektibilitas kriteria tersebut dalam kolektibilitas yang masih dapat diterima (perform) atau paling tinggi pada posisi Dalam Perhatian Khusus (DPK). Selain itu, efektivitas kriteria restrukturisasi juga berkesinambungan karena hasil dari pengukuran kolektibilitas triwulan setelah satu tahun restrukturisasi kolektibilitas nasabah juga masih dapat diterima (perform) atau paling tinggi pada posisi Dalam Perhatian Khusus (DPK).

\section{Daftar Pustaka}

Arsyad, Lincolin dan Suratno. 2008. Metodologi Penelitian Untuk Ekonomi dan Bisnis Edisi Revisi. Yogyakarta: STIM YKPN

Bungin, Burhan. 2008. Penelitian Kualitatif: Komunikasi, Ekonomi, Kebijakan Publik dan Ilmu Sosial lainnya. Jakarta: Kencana

Hidayati, Nur Laili. 2014. Pengaruh Pembiayaan Jual Beli, Pembiayaan Bagi Hasil, Pembiayaan Sewa, dan Rasio Non Performing Financing Terhadap Likuiditas Bank Umum Syariah di Indonesia. Skripsi Universitas Islam Negeri Maulana Malik Ibrahim

Hutasuhut, Dina Rizkiah. 2009. Pengaruh FDR, BOPO, dan NPF Terhadap Profitabilitas (ROE) Perbankan Syariah di Indonesia. Skripsi Universitas Sumatera Utara 
Herijanto, Hendy. 2013. Selamatkan Perbankan Demi Perekonomian Indonesia. Jakarta: Mizan Publika

Ika, Valentina Erista dan Mulyo Haryanto. Analisis Pengaruh CAR, KAP, NIM, BOPO, LDR, dan Senstitivy To Market Risk Terhadap Tingkat Profitabilitas Perbankan

Jath, Ar Razaq Subhan. 2013. Analisis Pengaruh Restrukturisasi Kredit Bermasalah (Non Performing Loan) pada perusahaan perbankan yang terdaftar di BEI

Khairunisa, Madona. 2013. Efektifitas Pelaksanaan Restruktursasi Pembiayaan Terhadap Penurunan NPF (Non Performing Financing) pada PT. Bank Riau Kepri Cabang Syariah Pekanbaru Tahun 2013. Tesis Universitas Islam Negeri Sultan Syarif Kasim Riau

Latvia, Wagny. 2013. Pengaruh Tingkat Non Performing Financing (NPF) Pembiayaan Murabahah Terhadap Tingkat Likuiditas (FDR) Pada PT. Bank Bukopin Syariah Periode 2009-2012. Skripsi Universitas Islam Bandung

Meilasari, Anneke Putri. 2014. Faktor-Faktor Yang Menghambat Nasabah Mengembalikan Pembiayaan Warung Mikro BSM. Jakarta: Skripsi Universtitas Islam Negeri Syarif Hidayatullah

Nurhalimah, Novianti. 2014. Penanganan Pembiayaan Murabahah Bermasalah Yang Disebabkan Force Majeure Pihak Nasabah. Artikel ilmiah Kementrian Pendidikan dan Kebudayaan Universitas Brawijaya

Oktaviani, Shelly. 2006. Perbandingan Perhitungan Indikator Kesehatan Bank Dengan Menggunakan CAMELS DAN CAMEL: Studi Kasus PT. Bank Lippo, Tbk Periode Tahun 2004-2006. Skripsi Universitas Gunadarma

Pamungkas, Lukito. Pengaruh Permodalan, Likuditas, Kualitas Aset Terhadap Profitabilitas Bank Umum Syariah Yang Terdaftar di Bank Indonesia. Skripsi Universitas Negeri Surabaya

Purwanto, Tri Joko. 2011. Analisis Besarnya Pengaruh Pembiayaan, Financing To Deposit Ratio (FDR) dan Rasio Non Performing Financing (NPF) Terhadap Bank Syariah (Studi Kasus PT. Bank Muamalat Indonesia, Tbk). Skripsi Institut Pertanian Bogor

Rustam, Bambang Rianto. 2013. Manajemen Risiko Perbankan

Syariah di Indonesia. Jakarta: Gramedia Pustaka Utama.

Setiawan, Dedy dkk. 2014. Upaya Hukum Penyelesaian Keterlambatan Pembayaran Bagi Hasil Oleh Nasabah Dalam Perjanjian Kredit Mudharabah Pada Bank BNI Syariah Cabang Samarinda. Jurnal Beraja Niti

Siagian, Sondang P. 2007. Teori Pengembangan Organisasi 
Siregar, Saparudin. 2013. Character Debitur Bank Syariah dalam memenuhi Kewajiban. Jurnal Tsaqafah

Solo Pos, tanggal 11/12/2015

Sumaryati, Eka. 2013. Tahukah Anda? Tentang PHK \& Pesangon. Jakarta: Dunia Cerdas

Syah, Hidayat. 2010. Pengantar Umum Metodologi Penelitian

Pendekatan Verifikatif. Pekanbaru: Suska Press

Syafi'i, Antonio. 2001. Bank Syariah dari Teori ke Praktik. Jakarta: Gema Insani

Wangsawidjaja. 2012. Pembiayaan Bank Syariah. Jakarta: Gramedia Pustaka Utama. www.btn.co.id

----------,2008. "Pembiayaan Bagi Bank Umum Syariah dan Unit

Usaha Syariah." dalam PBI 10/18/PBI/2008

---------, 2008. "Perbankan Syariah "dalam Undang-Undang

Republik Indonesia No. 21

--------, 1992. “Perbankan"dalam Undang-Undang Republik

Indonesia No. 7

--------, 2007. "Sistem Penilaian Tingkat Kesehatan Bank Umum

Berdasarkan Prinsip syariah" dalam PBI 9/1/PBI/2007

---------, 2007. "Sistem Penilaian Tingkat Kesehatan Bank Umum

Berdasarkan Prinsip Syariah" dalam SEBI 9/24/DPbS/2007

--------, 2005. "Kewajiban Penyediaan Modal Minimum Bank Umum

Berdasarkan Prinsip Syariah"dalam PBI 7/13/PBI/2005

--------, 2006. "Penilaian Kualitas Bank Umum yang Melaksanakan

Kegiatan Usaha Berdasarkan Prinsip Syariah"dalam PBI 8/21/PBI/2006

--------, 2011. "Penilaian Kualitas Aktiva Bagi Bank Umum Syariah dan

Unit Usaha Syariah."dalam PBI 13/13/PBI/2011

--------, 2011. "Penilaian Kualitas Aktiva Bagi Bank Umum Syariah dan Unit UsahaSyariah." dalam 13/10/DPbS/2011

---------, 2011. "Restrukturisasi Pembiayaan Bagi Bank Umum

Syariah dan Unit Usaha Syariah."dalam 13/9/PBI/2011

---------, 2011. "Restrukturisasi Pembiayaan Bagi Bank Umum

Syariah dan Unit Usaha Syariah" dalam SEBI 13/18/DPbS/2011

--------, 2008. "Restrukturisasi Pembiayaan Bagi Bank Umum

Syariah dan Unit Usaha Syariah" dalam SEBI 10/34/DPbS/2008

2003. "Ketenagakerjaan" dalam Undang-Undang Republik

Indonesia No. 13 